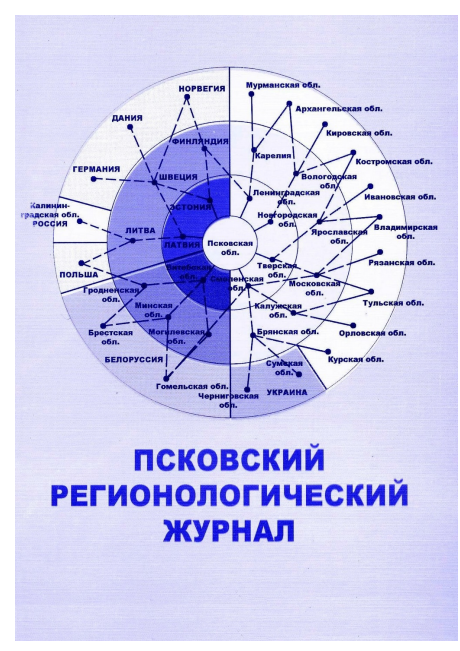

Псковский регионологический журнал. 2013-2023

ISSN 2219--7931

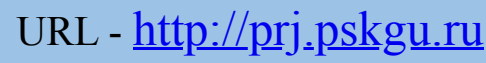

Все права защищены

Выпуск 2 (46) Том . 2021

\title{
Transformation of transport-geographic space of Central Asian countries in the Post-Soviet era
}

\author{
Федорко Виктор Николаевич \\ Secondary school №233 of the city of Tashkent \\ Uzbekistan, Tashkent
}

\begin{abstract}
Аннотация
The structural and morphological restructuring of the transport-geographic systems of the countries of Central Asia has become a reflection of the radical transformation of the geopolitical space of the region in the post-Soviet era. From the very beginning of a new period of development in the countries of the region, the disintegration of a single (endto-end) road transport framework that developed during the Soviet period was consistently taking place. This was due to the desire of the countries of the region to minimize their own transport dependence on neighbors, while simultaneously enhancing transport-logistics advantages to exert geopolitical pressure on neighboring states. Under the influence of the corresponding geostrategic landmarks, the countries of the region have consistently built a new configuration of transport-logistics systems during the post-Soviet period.
\end{abstract}

The article examines the changes in the geography of the main road transport communications of Uzbekistan, Turkmenistan, Tajikistan and Kyrgyzstan that have occurred over the past three decades. It was revealed that the most morphologically transformed transport systems of Uzbekistan and Turkmenistan, characterized by relatively favorable geomorphological conditions for transport construction and more significant economic opportunities. In the predominantly mountainous terrain of Tajikistan and Kyrgyzstan, which also have a significantly more modest investment potential, the transformation of the transport-geographic space has occurred to a less pronounced degree. Special attention is paid to the prospects for the reintegration of transport systems of the Central Asian countries, which emerged after 2016, in connection with the profound changes in Uzbekistan's foreign policy towards the border 
countries of Central Asia, initiated and consistently implemented by the new leadership of the republic, headed by President Shavkat Mirziyoyev.

Ключевые слова: transport-logistics systems, railways, highways, transport integrity of the territory, transport-geographic space, post-Soviet period

Дата публикации: 28.06.2021

\section{Ссылка для цитирования:}

Федорко В. Н. Transformation of transport-geographic space of Central Asian countries in the Post-Soviet era // Псковский регионологический журнал. - 2021. - Выпуск 2 (46) C. 14-30 . URL: https://prj.pskgu.ru/s221979310014232-8-1/. DOI: $10.37490 / \mathrm{S} 221979310014232-8$

1 Introduction. Central Asia is an original and integral political and geographical subregion of Eurasia, formed by five post-Soviet states - Kazakhstan, Kyrgyzstan, Tajikistan, Turkmenistan, and Tajikistan. The territory of these states has been developing for thousands of years as a single space in landscape-geographical, water irrigation, ethno-confessional, economic, transport relations. At the same time, the modern borders of Kazakhstan, Kyrgyzstan, Tajikistan, Turkmenistan, and Uzbekistan were formed during the Soviet period. However, before the collapse of the USSR, these borders were largely formal, and the economic and infrastructural space of the region was highly integral and unified.

2 At the same time, the unity of the network of road transport communications railways, highways, pipelines - was of great importance. Often, transport links between different regions of one republic were carried out through the territory of neighboring republics. For example, the railway connection of the Surkhandarya region with the main territory of Uzbekistan was carried out through the territory of the Chardzhou region of Turkmenistan, and the railway connection between Dushanbe and the cities of the Leninabad region of Tajikistan was carried out through the territory of Uzbekistan and Turkmenistan.

3 The road network in the region acquired an inter-republican pattern in the conditions of a single political and geographical space during the Soviet period, when communication routes (primarily railways) between densely populated oases were laid, as a rule, along with the territory of river valleys, bypassing mountain ranges and vast deserts with complex engineering and geographical conditions for road construction. At the same time, the crossing of the borders between neighboring republics by transport communications in the conditions of a single state, such as the former USSR, did not create any obstacles to the uninterrupted movement of transport.

4 However, the state of affairs in the functioning of cross-border transport systems changed radically after the collapse of the USSR and the proclamation of independence by the republics of the region. In the new geopolitical conditions, state borders have ceased to be formal, a visa regime has been introduced between some countries of the region, in particular, between Uzbekistan and Turkmenistan, Uzbekistan and Tajikistan, Uzbekistan and Kyrgyzstan. In the 1990s, relations between the Central Asian states became very tense, complicated by serious contradictions of national geo- 
economic interests, primarily in the fuel and energy sector (trade-in gas, oil, and petroleum products, the functioning of the unified energy system, electricity tariffs, etc.) and water management (transformation of operation regime of reservoirs by the mountainous countries of the region - Kyrgyzstan and Tajikistan - from irrigation and energy, supported in the Soviet period, to energy, which was due to the shortage of fuel and electricity in these states, especially in winter) [21]. The geopolitical importance of transport communications in the region has sharply increased as a factor in ensuring the territorial integrity, security, and sustainable socio-economic development of each of the Central Asian states, and at the same time as a lever of pressure on neighboring states in order to realize their own geopolitical advantages and ambitions.

5 In the post-Soviet period, the issues of developing and implementing national strategies for improving the transport and geographical position of the country and individual regions, diversifying the routes of international transport corridors through which foreign economic relations are carried out, strengthening transport independence and integrity, and modernizing transport and logistics systems have become relevant in all Central Asian states. At the same time, the key tasks for the transformation of the transport and geographical space in the Central Asian states were to a high degree identical, but the degree of severity of the corresponding problems and the possibilities of their solution in the countries of the region differed significantly. These differences were caused by the peculiarities of the economic and geographical location of states on the scale of Central Asia and neighboring regions of Eurasia, the orography and relief of the territory, the morphology of transport communications, as well as the financial and economic resources of countries in the region. The scale of implementation of the relevant tasks, which led to the restructuring of transport and logistics systems, also differs in the countries of the region, which will be discussed below, in the main part of the article.

6 The purpose of the study is to analyze the prerequisites, processes, and consequences of the structural and morphological transformation of the transport and geographical space of Uzbekistan, Turkmenistan, Tajikistan, and Kyrgyzstan, which occurred in the post-Soviet period, in the context of profound changes in the geopolitical and socio-economic situation in the region. Information about the construction of railways in the countries of the region is provided on the basis of official materials of state transport companies.

7 Previous studies. Issues of development of transport and logistics systems of Central Asian countries are considered in the works of many researchers from the countries of the region and other CIS countries, in particular, the Russian Federation. The problems and prospects of realizing the transit potential of the transport and logistics systems of the Central Asian states, the processes of integration and regionalization of the transport and communication space of the region are considered in the works $[4 ; 6-10 ; 12 ; 15 ; 19 ; 21]$. The issues of the development of transport systems of Uzbekistan in the post-Soviet period are covered in the studies of R. Nailev [14], M. N. Ravshanov [16], H. K. Umarov [20], V. Yarashova [22]. A number of publications by P. H. Asimova [1-3; 11], G. A. Gafurova [5], H. Saidov [18] are devoted to the factors and problems of the modern development of transport and logistics systems in Tajikistan. The transport and geographical problems of post-Soviet Kyrgyzstan are analyzed in the works of K. K. Rakhimov [17], E. D. Moldaliev [13]. However, the 
issues of structural and morphological restructuring of the transport and geographical systems of the Central Asian countries in the post-Soviet period have been little studied.

$8 \quad$ Results and discussion. Systemic efforts of the Central Asian States aimed at solving the problems outlined in the introduction have led to the fact that during the thirty-year post-Soviet period of history, the transport and geographical space of the region as a whole has undergone a significant morphological restructuring. These changes have had an impact on the geostrategic and geopolitical conditions of socioeconomic development of all countries in the region. At the same time, the degree and nature of the transformation of transport and logistics systems in each of the Central Asian states have their own significant features. In this regard, we will consider specific changes in the transport and geographical space of individual Central Asian states, while ignoring Kazakhstan, since its transport communications, due to the peculiarities of its state territory, initially differed in a high degree of integrity and unity compared to the other four countries of the region.

9 Uzbekistan. After gaining independence, Uzbekistan faced a number of transport and geographical problems, the most noticeable of which were the lack of diversification of transport corridors connecting the republic with the ports of the ocean, and the lack of territorial integrity of the railway network, the dependence of a number of regions on neighboring states for railway communication with the rest of the country. Since the first post-Soviet years, systematic measures aimed at solving these issues have been implemented in Uzbekistan.

10 Special attention was paid in the republic to the creation of an integral system of railway communications capable of connecting all regions of the country with a relatively cheap and reliable transport connection that does not depend much on the weather conditions of the winter period without crossing the state border. In particular, to ensure a stable railway connection with the north-western part of the country (the Republic of Karakalpakstan and the Khorezm region), where trains ran through the territory of Turkmenistan in the Soviet and first post-Soviet years, in 2001 the Uchquduq - Miskin - Nukus railway line was launched with a short branch towards the Khorezm region through the territory of the Kyzylkum desert. In the difficult mountainous conditions of the Hissar Ridge, the Tashguzar-Baysun - Kumkurgan railway was built by 2007, which allowed establishing a stable railway connection between the Surkhandarya region and the rest of Uzbekistan, which was previously carried out through the territory of Turkmenistan (the Qarshi - Kerki — Amu Darya - Termez railway line). This transport and geographical task was solved by 2016, when the Angren - Pap railway line was put into operation through the Kuramin Ridge, connecting the railways of the regions of the Ferghana Valley (Namangan, Andijan, Ferghana regions) with the Tashkent region, and through it with the rest of Uzbekistan. This made it possible to significantly revive the internal and external railway communication of the eastern regions of Uzbekistan, which were previously in a "dead end" position in the railway communications system of the republic due to the almost complete stop of train traffic from the Uzbek part of the Ferghana Valley through the Sughd region of Tajikistan to the Tashkent region (Bekabad).

11 In 2017, the construction of the Bukhara - Miskin railway was completed, which significantly reduced the time of train traffic in the direction of the Republic of 
Karakalpakstan and the Khorezm region, which is of great importance, first of all, for the intensification of domestic and inbound tourism in the republic, one of the key centers of which is Khiva in the Khorezm region. The close connection of railway construction in Uzbekistan with the tasks of creating an infrastructure favorable for the development of tourism in the country is confirmed by the fact that almost simultaneously with the Bukhara - Miskin highway, the railway connecting Urgench (the center of the Khorezm region) with Khiva was put into operation, which made it possible to provide a direct passenger railway connection between Tashkent and Khiva through Samarkand and Bukhara. Thus, all the most important tourist centers of Uzbekistan were connected by rail.

12 Electrification of the Samarkand - Bukhara - Miskin - Urgench - Khiva, Samarkand - Karshi — Shakhrisabz, Karshi — Tashguzar — Baysun - Kumkurgan - Termez and Angren - Pap - Kokand - Margilan - Andijan railways, as well as the launch of high comfort highspeed trains on the routes Tashkent - Samarkand ("Afrasiab"), Tashkent — Bukhara ("Shark") and Tashkent — Karshi ("Nasaf") contributed to improving the quality of railway communication between the main tourist cities of the republic. In the near future, it is planned to launch the high-speed railway passenger route "Great Silk Road" between Tashkent and Khiva. In general, the electrification of railways, which has been actively carried out in the republic over the past few years, has significantly increased the capacity of railways, reduced the cost of rail transportation, significantly reduced the travel time between the most remote regions of the republic.

13 The Republic of Uzbekistan, in order to ensure reliable transport access to seaports in several directions, to realize the transit opportunities of its economic and geographical location, carries out large-scale cooperation on transport development with such countries as Kazakhstan, the Russian Federation and China (in the north-west and north-east directions), Turkmenistan, Iran, Azerbaijan, Georgia, Turkey and Oman (in the south-west direction), showing interest in such global transport and logistics projects as the New Silk Road and TRACECA. In addition, negotiations are underway with Kyrgyzstan and China on the construction of the China - Kyrgyzstan - Uzbekistan railway.

14 The construction by Uzbekistan of the first railway on the territory of Afghanistan Termez - Mazar-i-Sharif became the first stage of the construction of the shortest access for Uzbekistan to the ports of the World Ocean in the southern direction. Currently, prospects are being outlined for the construction of the Mazar-i-Sharif Kabul - Peshawar Trans-Afghan railway, which will connect the railways of Uzbekistan and Pakistan.

15 Thus, the main directions of transformation of transport and logistics systems in the conditions of post-Soviet Uzbekistan were ensuring the territorial integrity of the railway network of the republic, electrification of railways, commissioning of highspeed railway routes connecting Tashkent with the leading tourist centers of the republic, and diversification of transport corridors connecting the republic with the ports of the World Ocean. The implementation of these tasks contributed to strengthening the transport independence and security of Uzbekistan, minimizing the risks of geopolitical pressure from neighboring countries in the transport and economic sphere. Ensuring the 
transport integrity of the territory of Uzbekistan and cooperation in the transport sphere with Kazakhstan and Turkmenistan to provide reliable transportation of goods to foreign markets has strengthened geopolitical and geo-economic demarcation of Uzbekistan with Tajikistan and Kyrgyzstan. At the same time, the transport "map" has clearly strengthened the position of Uzbekistan, while Tajikistan and Kyrgyzstan have gained a clear advantage in the water management aspect.

16 Turkmenistan. In the post-Soviet years, the main goals of Turkmenistan's transport policy were to ensure the territorial integrity of the railway network within the country and to maximize the transit potential of the country's economic and geographical position as a link between the transport communications of Central and South-West Asia. To achieve these goals, significant work has been done over the past three decades, as a result of which the transport network of the republic has been largely transformed.

17 In Soviet times, the railway connection between Ashgabat and Dashoguz was carried out through the territory of Uzbekistan on the Chardzhou - Kungrad highway passing through the Khorezm region of Uzbekistan. The eastern districts of the Chardzhou (now - Lebap) region, in particular, the cities of Kerki and Gaurdak (now - Magdanly) were also connected to the main part of the republic through the railways of the Kashkadarya and Bukhara regions of neighboring Uzbekistan. In the new geopolitical conditions, the urgency of providing a railway communication system between the capital, administrative centers and the main industrial cities of the regions of the republic without crossing the state border has arisen.

18 To ensure the territorial integrity of the railway network of Turkmenistan in the post-Soviet period, the Turkmenabat - Kerki railway line (1999), the Trans-Karakum railway on the Ashgabat - Dashoguz route (2006) and the railway bridge over the Amu Darya near Kerki (2009) were built and put into operation in the country, connecting the Kerki - Amu Darya and Turkmenabat - Kerki railways passing, respectively, on the right and left banks of the Amu Darya. This ensured the establishment of a stable railway connection between the northern region of the republic - Dashoguz region, as well as the eastern territories of the Lebap region with Ashgabat without crossing the state border with Uzbekistan. In addition, it is planned to build the Gazachak Shasenem - Dashoguz railway in Turkmenistan, which will provide a convenient, fast railway connection between the northern and eastern regions of the republic without the need to transit through the Khorezm region of neighboring Uzbekistan or travel along the very long Dashoguz - Ashgabat — Turkmenabat route on its own territory. This will complete the formation of the ring configuration of the railways of Turkmenistan.

19 Throughout the entire post-Soviet period, transport and logistics projects aimed at increasing the transit potential of the republic have been consistently implemented in Turkmenistan. The first step in this direction was the opening in 1996 of the Tejen Serakhs - Mashhad railway, which connected the railways of Iran with the railway communications of Turkmenistan, and through them, with the railways of the whole of Central Asia. In 2014 the construction of the Uzen - Gyzylgaya - Bereket - Etrek Gorgan railway, also known as the Kazakhstan - Turkmenistan - Iran railway, was completed. This road is an important part of the international North-South transport corridor and significantly enhances the transport and geographical importance of 
Turkmenistan in the regional network of railway communications of the Central Asian region.

20 The construction of the Turkmenistan - Afghanistan - Tajikistan railway (Trans-Afghan Railway), a memorandum on the construction of which was signed by the presidents of the three states in Ashgabat on March 20, 2013, is considered as an important factor in strengthening the transit potential of Turkmenistan in the future. In 2016, the construction of the Turkmen section of the Kerki - Imamnazar - Akina highway was completed, and in January 2021, with the participation of the Presidents of Turkmenistan and Afghanistan, the first section of this highway was opened on the territory of Afghanistan, Akina - Andkhoy, with a length of $30 \mathrm{~km}^{7}$. Thus, Turkmenistan has created an alternative route to the Termez - Mazar-i-Sharif railway for external railway communication in Afghanistan. However, the prospects for completing the construction of the Trans-Afghan Railway in its intended form and scale remain very uncertain.

21 As part of the implementation of a long-term strategy to turn Turkmenistan into an important part of the transport and logistics communications of Eurasia, the republic actively cooperates in the transport sector not only with Iran, Afghanistan, Tajikistan and Kazakhstan, as mentioned above, but also with Uzbekistan, despite the systematic and consistent refusal to use railways on the territory of Uzbekistan for communication between Ashgabat and the northern and eastern regions of the country. Back in 2011, the Ashgabat Agreement on the Establishment of the Uzbekistan - Turkmenistan - Iran - Oman International Transport and Transit Corridor was signed, which entered into force in Uzbekistan on April 23, 2016. As part of the work under this agreement, new railway and road bridges across the Amu Darya in Turkmenistan were opened in 2017. The full implementation of the Ashgabat Agreement will provide a convenient and relatively short route between the countries of Central Asia and the ports of the Persian and Oman Gulfs.

22 In addition, Turkmenistan is an active participant in the international transport program for the creation of the Europe - Caucasus - Asia corridor (TRACECA), one of the key nodes of which is the Turkmenbashi seaport on the Caspian Sea, which is a kind of "sea gate" of Central Asia. Consistent work is being carried out in the republic to modernize and increase the capacity of the Turkmenbashi seaport. This work, together with the development of the railway network of international importance, is of great importance for strengthening the transport and geographical potential of Turkmenistan in the network of transport corridors of Eurasia.

23 Thus, in the post-Soviet years, Turkmenistan underwent a significant transformation first of all, the railway network, which gained internal integrity and grew a number of exits to the transport systems of neighboring countries (Kazakhstan, Iran, Afghanistan), ensuring the strengthening and growth of the transit potential of the republic, its geopolitical and geostrategic capabilities as a link between the countries of Central and South-West Asia.

24 Tajikistan. For Tajikistan in the post-Soviet period, the improvement of transport and logistics systems has become one of the most urgent problems. Located mainly within the impassable mountain systems of the Pamir and Gissar, Tajikistan after 
the collapse of the USSR was actually in a transport impasse, which is one of the key factors limiting the socio-economic development of the country. The territory of Tajikistan is not intersected by railways and highways of international importance, which makes it more difficult for foreign economic relations of the republic and reduces the competitiveness of its products in foreign markets.

25 In addition, a number of high mountain ranges, in particular, Turkestan, Zeravshan and Hissar, divide the country into poorly connected parts in terms of transport and logistics. Thus, during the Soviet period, the railway connection between Dushanbe and Kurgan-Tube (now Bokhtar) was carried out through the territory of Uzbekistan, and between Dushanbe and Leninabad (now Khujand) through the territories of Uzbekistan and Turkmenistan.

26 Already in the first years of the post-Soviet era, as relations with the Uzbekistan deteriorated, whose transport communications play an extremely important role in both external and internal relations of Tajikistan, the latter faced serious problems in the transport and logistics sphere. In particular, after trains stopped running on the Dushanbe - Khujand and Dushanbe - Kurgan-Tube routes in transit through Uzbekistan, the northern, central and southern regions of the republic could only be connected by road or air transport. However, the Dushanbe-Khujand highway passes through the Anzob (Hissar ridge) and Shahristan (Turkestan Ridge), which are usually closed for up to six months a year due to weather conditions, which is why the northern regions of Tajikistan (Sughd region) in winter actually become cut off from the rest of the country. A similar situation was observed on the Dushanbe - Kulyab highways connecting the capital of the republic with the Khatlon region, passing through the Sharshar pass, and DushanbeDangara, crossing the Chormagzak pass.

27 To ensure automobile communication between the capital of Tajikistan and its northern region, the "Istiqlol" mountain automobile tunnels were built through the Hissar Ridge (opened in 2006) and Shahristan through the Turkestan Ridge (opened in 2012), which are now the longest automobile tunnels in the CIS countries. After their opening, year-round traffic was provided along the Dushanbe - Khujand - Chanak highway, which became the first toll road in Central Asia. In parallel, there were the "Ozodi" automobile tunnels (on the Dushanbe — Kulyab highway, opened in 2009) and Khatlon (on the Dushanbe - Dangara highway, opened in 2013) were built, which strengthened the transport connection between the central and southern regions of Tajikistan.

28 For the development of sustainable road communication between Tajikistan and neighboring countries, the construction of such international highways as Dushanbe Jirgatal - Sary-Tash, connecting Tajikistan with Kyrgyzstan, and Dushanbe - Kulyab — Kalai-Khumb - Khorog — Murgab - Kulma - Kashgar, connecting the republic's road network with the Xinjiang Uygur Autonomous Region of the People's Republic of China, was necessary.

29 After the collapse of the USSR, the railway network of Tajikistan was divided into three regional bushes that were not connected to each other on the territory of the republic: the northern one, on the territory of the Sughd region (the Nau - Shurab line), the central one, on the territory of the republican subordination districts (the Pakhtaabad 
- Dushanbe - Vakhdat line), and the southern one, within the Khatlon region (the Khoshadi - Yavan line with the Bokhtar branch — Kulyab).

30 After the rails on the Galaba - Amuzang line were dismantled in Uzbekistan in 2011, which became the high point of the transport confrontation between the two neighboring countries, the southern bush of the railways of Tajikistan was completely isolated. In order to connect the central and southern sections of the railways of Tajikistan, the construction of the Vakhdat-Yavan railway was accelerated, which was completed in 2016. This road became the second railway line built in the territory of Tajikistan in the post-Soviet period after the Kurgan-Tube-Kulyab road, which was put into operation in 1999. The morphological transformation of the railway network of the republic in the post-Soviet period lies in the construction of these two lines.

31 In recent years, Tajikistan has been actively working on options for the construction of several international railway corridors that can lead Tajikistan out of the transport impasse and significantly reduce the republic's transportnological dependence on neighboring Uzbekistan, in particular, the previously mentioned Tajikistan Afghanistan - Turkmenistan railway, a section of which has already been built and brought to the territory of Afghanistan, as well as the railways Tajikistan - Kyrgyzstan Kazakhstan - Russia and China - Kyrgyzstan - Tajikistan - Afghanistan - Iran. However, these projects are still either under discussion or at the stage of technical and economic design and expertise, and the construction of these railway tracks has not yet begun on the territory of Tajikistan. In general, the prospects for the implementation of these transport and logistics projects remain unclear.

32 Thus, the geopolitical realities that have developed in Central Asia in the postSoviet years have put Tajikistan in front of the need to solve the most acute problems of overcoming the transport impasse, overcoming logistical dependence on neighboring Uzbekistan, with which relations were often not easy at all, and forming an integral internal transport and geographical space. As part of the solution of this complex of geostrategic tasks in Tajikistan in the post-Soviet period, significant work was carried out to modernize the road network, which acquired a largely new morphology and became the supporting framework of the national economy and the settlement system of the republic. At the same time, the difficult mountainous terrain and the difficult financial and economic situation of the republic limit the implementation of ambitious projects in the field of railway transport, which could radically improve the state of affairs in the transport and communication sphere of Tajikistan, and the railway network of the republic in the analyzed period was transformed to a much lesser extent compared to Uzbekistan and Turkmenistan. Although there are some achievements in this part of the transport and logistics system of Tajikistan, the main one is the unification of the previously disparate central and southern sections of the country's railways.

33 Kyrgyzstan. For Kyrgyzstan in the post-Soviet era, the improvement of the territorial organization of the transport system has become one of the most urgent strategic tasks of socio-economic and geopolitical development. This was predetermined by the internal fragmentation of roads and, especially, railways connecting various regions of the republic, and their close intertwining with the transport communications of neighboring countries-Uzbekistan and Tajikistan. Such a morphology of the transport network of Kyrgyzstan was formed under the direct influence of the impassable 
mountainous terrain of the Tien Shan, whose ridges occupy about 9/10 of the territory of Kyrgyzstan, and a very rugged state border line in the southern part of the republic (Ferghana Valley), where a number of exclaves of Uzbekistan and Tajikistan are located (Shakhimardan, Sokh, Vorukh, etc.).

34 The railway network of Kyrgyzstan was formed in the Soviet years and it consists of several spatially disparate, unrelated lines in the north and south of the country. The northern section of the railways of the republic consists of the Lugovaya Balykchi highway connecting the Chui and Issyk-Kul regions with neighboring Kazakhstan. The southern section includes short lines connected to the territory of neighboring Uzbekistan: Kuvasai - Kyzylkiya, Osh - Kara-Suu, Jalalabad - KokJangak and Shamaldysai — Tashumyr. During the Soviet period, railway communication between the southern and northern regions of the republic was carried out through the territory of Uzbekistan, Tajikistan and Kazakhstan. However, already in 1993, the railway connection between the north and the south of Kyrgyzstan ceased. Currently, the railways of the southern regions of Kyrgyzstan are not actually used due to the fact that they are short and connected only through the territory of Uzbekistan. Accordingly, only the Lugovaya-Balykchi railway line is used for cargo and passenger communication between Kyrgyzstan and neighboring Kazakhstan, and through its territory with Russia, and for domestic purposes within the Chui and Issyk-Kul regions.

35 The suspension of railway communication between the southern regions of Kyrgyzstan - the city of Osh, Osh, Jalalabad and Batken regions with neighboring Uzbekistan and with the north of the country, in particular, with the capital of the republic, has put these territories in a state of transport deadlock. This situation, against the background of difficult relations with neighboring Uzbekistan and Tajikistan, complicated the already problematic socio-economic development of this part of the Ferghana Valley and put on the agenda the most acute geopolitical problem of connectivity by aggravating the traditional division of Kyrgyz society into North and South, which has repeatedly led to far-reaching consequences in all spheres of life of the republic at the post-Soviet stage of its history.

36 Since the mid-1990s, plans have been discussed in Kyrgyzstan for the construction of a railway with the conditional name Chui - Ferghana to ensure a stable railway connection between the north and south of the republic [17]. However, the construction of the railway on the Balykchi - Kochkor - Jalalabad route, which began in 1998, was stopped due to financial difficulties in 2000.Therefore, until now, the only transport route connecting the north and south of the country is the Bishkek - Osh highway, traffic on which is sometimes suspended during the winter months for meteorological reasons. At such moments, only the air service between Osh and Bishkek provides a connection between the capital of the republic and its southern regions.

37 Another large-scale transport project, widely discussed for a long time in Kyrgyzstan, is the China - Kyrgyzstan - Uzbekistan railway, on which certain hopes are pinned in the republic to break the transport deadlock and diversify strategic transport routes, which contributes to reducing Kyrgyzstan's transport dependence on neighboring Kazakhstan. However, the prospects for the implementation of this project remain very vague for a number of reasons, in particular, difficult engineering and geological conditions of construction, differences in the gauge of railways in China and 
the post-Soviet states of Central Asia, as well as the ambiguity of the economic consequences for Kyrgyzstan, which, given the lack of its own investment resources for the construction of an expensive high-altitude highway, can count on attracting foreign, primarily, Chinese investments for the corresponding purpose are only secured by the transfer to foreign use of rich deposits of gold and rare metals, aluminum ores, coal in the central regions of the republic.

38 To date, no new railway communications have been built in post-Soviet Kyrgyzstan, which makes Kyrgyzstan the only country in Central Asia where the operational length of railway tracks has not only not increased, but also decreased during the reviewed period.

39 The situation in the road transport system of the republic remains very difficult. Thus, the projects "Alternative North - South Highway" and the Osh - Batken Isfana highway bypassing the enclaves of Uzbekistan and Tajikistan located within the Batken region in the south-west of the country remain unrealized.

40 Thus, it can be concluded that the problems of improving the transport and geographical position of Kyrgyzstan, the diversification of international transport corridors connecting the republic with the outside world, and ensuring the transport integrity and connectivity of the country's territory, primarily its northern and southern regions, remain unresolved to this day.

41 Positive trends in the field of transport integration in the region in recent years. Over the past few years (since the end of 2016), there have been clear positive changes in the establishment of mutually beneficial cross-border cooperation in Central Asia, some progress in solving the problems that have accumulated in this area. These circumstances are mainly due to the constructive and pragmatic geopolitical and foreign economic initiatives of the new leadership of Uzbekistan headed by the President of the Republic Mirziyoyev. A number of state visits of the head of Uzbekistan to neighboring countries that have been made in a relatively short time, in particular, the first official visits to Kyrgyzstan and Tajikistan in many years (relations between Tashkent and Dushanbe were particularly tense in 2010-2016), showed the firm interest and political will of the new leadership of the country in establishing constructive relations with neighboring states. We will briefly consider the most important directions of the "reset" of cross-border cooperation of the Central Asian countries in the transport sector, which is taking place during the implementation of the updated foreign policy strategy of Uzbekistan.

42 Since the coming to power of Mirziyoyev, many significant steps have been taken to strengthen the mutual integration of transport and communication systems of Uzbekistan and neighboring Central Asian states. Special attention should be paid to the processes of cardinal improvement of transport cooperation between Uzbekistan and Tajikistan and Kyrgyzstan, which, as the above analysis showed, suffered the most from the disintegration of the unified transport and geographical space of the region in the post-Soviet era. The most significant fact, perhaps, was the complete restoration of the Galaba - Amuzang railway, which was dismantled in 2011, connecting the Khatlon region of Tajikistan with the Surkhandarya region of Uzbekistan, in March 2018, on the eve of Mirziyoyev's state visit to Tajikistan [21]. This contributed to the improvement of 
the economic and geographical position of the Khatlon region of Tajikistan, in particular, its largest cities Bokhtar and Kulyab (regular passenger train traffic on the Kulyab Moscow route was restored), strengthened the transit potential of the Surkhandarya region, which occupies a peripheral economic and geographical position relative to the main part of Uzbekistan. Also in recent years, communication has resumed along the Penjikent - Samarkand highway connecting the Gorny valley Zarafshan (Tajikistan) with the densely populated Samarkand oasis of Uzbekistan, air traffic between Tashkent and Dushanbe was restored, which was discontinued at the dawn of the post-Soviet period, in 1992. Currently, work has begun on the electrification of the Northern section of the Railways of Tajikistan, fully funded by Uzbekistan. In general, the restoration of transport communications, the opening of more than ten checkpoints on the Uzbek-Tajik border and, most importantly, the abolition of the visa regime between Uzbekistan and Tajikistan contributed to the growth of trade turnover between them by 30 times over the period 2015-2019.

43 Great changes have occurred in the transport communication between Uzbekistan and Kyrgyzstan. Thus, in the Ferghana Valley, a number of checkpoints along the perimeter of the Uzbek-Kyrgyz border were opened for road transport, an agreement was concluded on the provision by Uzbek Railways of $30 \%$ discounts on all types of cargo when they are transported to the south of Kyrgyzstan in transit through the territory of Uzbekistan, regular bus service of the Sokh and Shakhimardan exclaves with the main part of the Ferghana region, as well as on the Osh - Andijan and Osh Ferghana routes was established. These measures, together with the relaxation of the visa regime between Uzbekistan and Kyrgyzstan, led to the intensification of trade and migration ties between the border regions of the Uzbek and Kyrgyz parts of the Ferghana Valley. In addition, an air service was opened between Tashkent and Osh, a regular bus route Tashkent - Bishkek was opened, the Balykchi — Tashkent Balykchi railway route was launched, connecting the capital of Uzbekistan with the coast of Issyk-Kul, the international road corridor Tashkent - Andijan — Osh Irkeshtam - Kashgar for cargo transportation began to operate. All this contributed to the intensification of trade turnover between Uzbekistan and Kyrgyzstan, which increased almost 5 times in 2016-2019.

44 Thus, after a period of consistent disintegration of the transport and geographical space of Central Asia that lasted for a quarter of a century, which led to a structural and morphological restructuring of transport and logistics systems in the countries of the region, in the last 4-5 years (after 2016), there have been progressive trends in the intensification of transport cooperation in the region. Priority in initiating these changes belongs to the leadership of the Republic of Uzbekistan, headed by President Mirziyoyev, who launched a comprehensive "reset" of relations with neighboring Central Asian countries. These trends open up prospects for the revival of a single transport and geographical space in Central Asia, supplemented by a number of created in the post-Soviet period, there are new routes, the formation of new international transport corridors that can ensure stable communication between the countries of the region and with the geospatial Eurasia surrounding Central Asia, including seaports of different states of the continent. All this will contribute to the realization of the transit potential of the Central Asian countries and the diversification of transport routes that bring their goods to foreign markets, and consequently, the 
intensification of foreign economic relations of the states among themselves and with other Eurasian countries.

45 Conclusions. Since the beginning of the 1990s, the trend towards the disintegration of a single transport and geographical space has become clearly evident in the countries of Central Asia, and the interdependence of transport and communication systems of the countries of the region has become an instrument of geopolitical pressure on neighboring states. Under these conditions, Uzbekistan, Turkmenistan, Tajikistan and Kyrgyzstan began to build a new configuration of strategic transport arteries - railways and highways, which would ensure the transport integrity of the state territory and independence from neighboring states, while contributing as much as possible to the realization of the country's transit potential and its integration into key transport corridors of Eurasia.

46 To the greatest extent, Uzbekistan and Turkmenistan have succeeded in solving the relevant tasks, which have managed to put into operation a number of new railways and highways since the collapse of the USSR, which have provided stable transport links between all regions without crossing the border with neighboring states, as well as the integration of national transport and logistics systems with the countries of SouthWest Asia and the Caucasus.

$47 \quad$ Tajikistan solved the problem of the transport integrity in difficult mountainous conditions only in the road transport system, while эrail transport provided only the connection of the previously separated Central (Hissar) and Southern (Khatlon) sections of railways. In addition, Tajikistan is still dependent on neighboring Uzbekistan for rail communication with the world.

48 In Kyrgyzstan, against the background of a clear decline in transport and geographical opportunities in the new geopolitical conditions, both railways and highways, no strategically significant transport and logistics projects were implemented in the post-Soviet years, and the problem of the transport integrity of the territory and the general situation of the country in the transport impasse remains unresolved, being one of the key factors limiting the socio-economic development of the southern and central regions of the republic.

49 After 2016, due to the tangible improvement of the geopolitical "climate" in the Central Asian region, initiated mainly by the new political leadership of Uzbekistan headed by President of the Republic Mirziyoyev, trends began to manifest themselves in the reintegration of national transport and logistics systems in the region with the prospect of their subsequent involvement in the largest transport corridors of Eurasia. These processes open the contours of building a new structural and morphological configuration of the transport and geographical space of Central Asia, where, obviously, an important place will be occupied by both the old "through" road communications that lost in the post-Soviet years, and the new highways built during this period.

\section{Библиография:}

1. Azimov P. Kh. (2016), Prospects for transport-logistics activities in the Republic of Tajikistan, Vestnik Yuzhno-Ural'skogo gosudarstvennogo universiteta. Seriya 
“Ekonomika i menedzhment”, vol. 10, no. 4, pp. 165-169. (In Russ.).

2. Azimov P. Kh. (2017), Problems and prospects for the development of the transportlogistics system of the Republic of Tajikistan, Vestnik Udmurtskogo universiteta. Seriya Ekonomika i pravo, vol. 27, no. 1, pp. 7-12. (In Russ.).

3. Azimov P. Kh. (2018), The network of transport-logistics centers in the Republic of Tajikistan as a factor in the development of national and international entrepreneurship, Ekonomicheskie i social'no-gumanitarnye issledovaniya, 2018, no. 2 (18), pp. 5-11. (In Russ.).

4. Bekmagambetov M. M. (2009), Using the transit transport potential of the Central Asian countries: challenges and opportunities, Almati, 64 p. (In Russ.).

5. Gafurova G. A. (2016), The first steps of the Republic of Tajikistan to overcome the transport impasse, Uchyonye zapiski Hudzhandskogo gosudarstvennogo universiteta imeni akademika B. G. Gafurova, no. 1 (46), pp. 28-35. (In Russ.).

6. Golubchikov Yu. N., Rahimov K. K., Sobyanin A. D., Tikunov V. S. (2012), Geographical justification of the Indo-Siberian transport direction, Geografiya i prirodnye resursy, no. 3, pp. 168-172. (In Russ.).

7. Zheleznyakov A. S., Tikunov V. S., Golubchikov Yu. N., Rahimov K. K., Sobyanin A. D. (2011), Railway models of integration of Central Eurasia, Teoriya i praktika obshchestvennogo razvitiya, no. 8, pp. 105-110. (In Russ.).

8. Zoidov K. Kh., Medkov A. A. (2015), Formation of management mechanisms for the development of the transit economy of the Central Asian countries in the context of integration and instability, Upravlenie, no. 3 (19), pp. 39-47. https://doi.org/10.12737/13336. (In Russ.).

9. Zokhidov A. A. (2014), Alternative transport corridors in Central Asia: factors, interdependence and integration issues, Central'naya Aziya i Kavkaz, vol. 17, no. 1, pp. 167-177. (In Russ.).

10. Zokhidov A. A. (2020), Central Asian transport system: joint coordination initiatives, challenges and solutions, Ekonomika Central'noj Azii, vol. 4, no. 3, pp. 185-196. (In Russ.).

11. Katochkov V. M., Azimov P. Kh. (2017), Conceptual provisions for the formation of the transport and logistics system of the Republic of Tajikistan // Vestnik YuzhnoUral'skogo gosudarstvennogo universiteta. Seriya "Ekonomika i menedzhment", vol. 11, no. 4, pp. 142-149. (In Russ.).

12. Krapchina L. N. (2018), Trends in geoeconomic and geopolitical processes in the Central Asian region of the post-Soviet space, Ekonomicheskie otnosheniya, no. 3, pp. 323-332. https://doi.org/10.18334/eo.8.3.39283. (In Russ.). 
13. Moldaliev E. D. (2016), State and development trend of the road transport industry in the Kyrgyz Republic, Tekhnicheskie nauki - ot teorii k praktike, no. 1 (49), pp. 151157. (In Russ.).

14. Nailev R. (2019), Transport qualification of Uzbekistan, Ekonomicheskoe obozrenie, no. 11, pp. 62-69. (In Russ.).

15. Increasing trade and transport connectivity and development of cargo transportation in Central Asia. International transport forum. URL: https://www.itf-

oecd.org/sites/default/files/docs/svyaznost-gruzovoy-transport-centralnaya-aziya.pdf (In Russ.). (accessed 26.02.2021).

16. Ravshanov M. N. (2012), Development of the road transport complex of the Republic of Uzbekistan, Ekonomicheskoe vozrozhdenie Rossii, no. 1 (31), pp. 221-226. (In Russ.).

17. Rakhimov K. K. (2012), Construction of the trans-Kyrgyz railway "Chui-Fergana", Bishkek, 123 p. (In Russ.).

18. Saidov Kh. (2010), Economic and geographical features of the development of the transport complex of the Republic of Tajikistan: dis.... PhD geogr. sciences, Dushanbe, 171 p. (In Russ.).

19. Turaeva M. O. (2014), Transport infrastructure of the Central Asian countries in the context of modern regionalization: Report, Moscow, 62 p. (In Russ.).

20. Umarov Kh. K., Svincov E. S. (2014), Construction of the Angren-Pap railway line and its role in the formation of the railway network of the Republic of Uzbekistan, Izvestiya Peterburgskogo gosudarstvennogo universiteta putej soobshcheniya, no. 4, pp. 80-86. (In Russ.).

21. Fedorko V. N. (2018), Processes of cross-border interaction in the countries of Central Asia: a new stage, Baltic Region - Region of Cooperation-2018: Problems and Prospects of Cross-Border Cooperation along the Western Border of Russia. Materials of the international scientific and practical conference, Kaliningrad, pp. 100-113. (In Russ.).

22. Yarashova V. (2020), Transport logistics of Uzbekistan in macroeconomic and transit aspects, Ekonomicheskoe obozrenie, no. 10, pp. 66-73. (In Russ.). 


\title{
Transformation of transport-geographic space of Central Asian countries in the Post-Soviet era
}

\author{
Viktor Fedorko \\ Secondary school №233 of the city of Tashkent \\ Uzbekistan, Tashkent
}

\begin{abstract}
The structural and morphological restructuring of the transport-geographic systems of the countries of Central Asia has become a reflection of the radical transformation of the geopolitical space of the region in the post-Soviet era. From the very beginning of a new period of development in the countries of the region, the disintegration of a single (endto-end) road transport framework that developed during the Soviet period was consistently taking place. This was due to the desire of the countries of the region to minimize their own transport dependence on neighbors, while simultaneously enhancing transport-logistics advantages to exert geopolitical pressure on neighboring states. Under the influence of the corresponding geostrategic landmarks, the countries of the region have consistently built a new configuration of transport-logistics systems during the post-Soviet period.

The article examines the changes in the geography of the main road transport communications of Uzbekistan, Turkmenistan, Tajikistan and Kyrgyzstan that have occurred over the past three decades. It was revealed that the most morphologically transformed transport systems of Uzbekistan and Turkmenistan, characterized by relatively favorable geomorphological conditions for transport construction and more significant economic opportunities. In the predominantly mountainous terrain of Tajikistan and Kyrgyzstan, which also have a significantly more modest investment potential, the transformation of the transport-geographic space has occurred to a less pronounced degree. Special attention is paid to the prospects for the reintegration of transport systems of the Central Asian countries, which emerged after 2016, in connection with the profound changes in Uzbekistan's foreign policy towards the border countries of Central Asia, initiated and consistently implemented by the new leadership of the republic, headed by President Shavkat Mirziyoyev.
\end{abstract}

Keywords: transport-logistics systems, railways, highways, transport integrity of the territory, transport-geographic space, post-Soviet period

Date of publication: 28.06 .2021

\section{Citation link:}

Fedorko V. Transformation of transport-geographic space of Central Asian countries in the Post-Soviet era // Pskov Journal of Regional Studies. - 2021. - Issue 2 (46) C. 14-30 
. URL: https://prj.pskgu.ru/s221979310014232-8-1/. DOI: 10.37490/S221979310014232-8

Код пользователя: 0; Дата выгрузки: 26.04.2023; URL - http://prj.pskgu.ru/s221979310014232-8-1/ Все права защищены. 